\title{
Purification and Characterization of a Lectin-Like Substance from Silkworm Faeces
}

\author{
Etsuko Hirayama, Naomi Ishikawa, Tomoyo Yano-Inoue, and Jeman Kim* \\ Institute of Molecular and Cellular Biology for Pharmaceutical Sciences, Kyoto Pharmaceutical University, \\ I-Shichonocho, Misasagi, Yamashina-ku, Kyoto 607, Japan
}

Key words: lectin/silkworm faeces/glycoprotein/cell detachment/cell aggregation

\begin{abstract}
$A B S T R A C T$. To obtain biologically active substances that are useful in the study of cell structures and functions, we examined several biological activities of an extract of silkworm faeces with hot buffer. We detected a lectinlike substance in the extract and purified it.

When the extract of silkworm faeces was added to a culture of quail myoblasts transformed with temperaturesensitive Rous sarcoma virus (QM-RSV cells), the plated cells which were cultured at $35.5^{\circ} \mathrm{C}$ (the permissive temperature for RSV that suppresses myogenic differentiation) became detached from the dishes and the cells in suspension aggregated. However, when the same amount of extract was added to plated QM-RSV cells cultured at $41^{\circ} \mathrm{C}$, which is a nonpermissive temperature for $\mathrm{RSV}$, the cells did not become detached. Other kinds of plated cells examined also did not become detached. Unlike plated cells, nonplated cells of all kinds aggregate in suspension upon the addition of the extract.

This active substance was purified by monitoring its induction of cell aggregation . The purified substance was found to be a lectinlike glycoprotein with an apparent molecular mass of about $60 \mathrm{kDa}$. Further studies showed that the binding sites of this glycoprotein are sugar chains on the cell surface and that mannose is an epitope.
\end{abstract}

In cell biology, it is important to obtain information of the structures and functions of the cell, which is a basal unit of any organism. An effective way to study cell structures and functions is to observe the responses of cells to stimuli. Hence, substances with biological actions on cells can be very useful for studying cell structures and functions. In this work, in an attempt to obtain such substances, we examined silkworm faeces, because the silkworm makes a unique protein, silk protein, silkworm faeces can be obtained cheaply in large quantities, and they have been used as a folk medicine in Korea.

We obtained a water-soluble extract from silkworm faeces, and examined several biological activities in this extract. We found that the extract caused detachment of plated QM-RSV cells, which are quail myoblasts

\footnotetext{
* Author to whom all correspondence should be addressed.

Abbreviations: QM, quail myoblasts; RSV, Rous sarcoma virus; C-RBC, chick red blood cells; B cells, B lymphocytes; T cells, T lymphocytes; ETC, Ehrlich ascites tumor cells; DMEM, Dulbecco's modified Eagle's medium; FCS, fetal calf serum; MEM, minimum essential medium; CS, calf serum; PBS $(-)$, calcium- and magnesium-free phosphate-buffered saline; SDS-PAGE, SDS-polyacrylamide gel electrophoresis; Con A, concanavalin A; WGA, wheat germ agglutinin; E-PHA, Phaseolus vulgaris lectin; EDTA, ethylenediaminetetraacetic acid; EGTA, glycoletherdiaminetetraacetic acid; NCAM, neural cell adhesion molecule.
}

(QM) transformed with temperature-sensitive Rous sarcoma virus (ts-RSV). QM-RSV cells proliferate at $35.5^{\circ} \mathrm{C}$, the permissive temperature for RSV at which the cells do not show myogenic differentiation, but differentiate at $41^{\circ} \mathrm{C}$, the nonpermissive temperature for RSV: on the shift up to $41^{\circ} \mathrm{C}$, the cells fuse with each other, and show biochemical differentiation with formation of multinucleated myotubes within $24 \mathrm{hr}(8,9)$. This system is thus very convenient for examination of myogenic differentiation, and we have been using it to study the mechanism of myoblast fusion. In this system, detachment of plated cells is observed in culture at $35.5^{\circ} \mathrm{C}$, but not at $41^{\circ} \mathrm{C}$. Then, we considered the possibility of using this system for analysis of QM-RSV cell differentiation and attempted to purify an active substance causing cell aggregation at $35.5^{\circ} \mathrm{C}$. As described in this paper, we first isolated a lectinlike glycoprotein with an apparent molecular mass of about $60 \mathrm{kDa}$ from silkworm faeces and examined its characteristics.

\section{MATERIALS AND METHODS}

Cells. Primary quail myoblast (QM) cells and QM-RSV cells were prepared as described previously $(8,9)$. Briefly, pectoral muscles from quail embryos were minced and myoblasts were dissociated by treatment with trypsin. After removal of fi- 
broblasts, the myoblasts were used as QM cells. QM cells transformed with a temperature-sensitive mutant of Rous sarcoma virus (ts-RSV) were used as QM-RSV cells.

Chick red blood cells (C-RBC) were prepared from blood harvested from a wing vein of White Leghorn chicks.

Mouse B lymphocytes (B cells) and T lymphocytes (T cells) were prepared from the spleen of a male 4-week-old ddy mouse using nylon fiber. Nylon fiber for separation of T cells was obtained from Wako Pure Chemical Industries (Osaka, Japan).

Ehrlich ascites tumor cells (ETC) were grown intraperitoneally in a ddy male mouse.

Cell culture. Dulbecco's modified Eagle's medium (DMEM) supplemented with $2 \mathrm{mM}$ glutamine, penicillin (100 units $/ \mathrm{ml})$, and streptomycin $(0.1 \mathrm{mg} / \mathrm{ml})$ was used as culture medium for QM and QM-RSV cells. In addition, this medium was supplemented with fetal calf serum (FCS) at $20 \%$ for use as growth medium and at $5 \%$ for use as differentiation medium. The cells were grown at $35.5^{\circ} \mathrm{C}$, and induced to differentiate at $41^{\circ} \mathrm{C}(8,9)$.

For treatment of QM-RSV cells with the crude extract of silkworm faeces, purified fraction, or concanavalin A (Con A), the cells were seeded at a density of $2 \times 10^{5}$ cells per $35-\mathrm{mm}$ diameter plastic dish coated with collagen (Type I-P, Nitta Gelatin, Yao City, Osaka, Japan) in $2 \mathrm{ml}$ of growth medium. They were precultured at $35.5^{\circ} \mathrm{C}$ for $24 \mathrm{hr}$ in growth medium and then cultured at $35.5^{\circ} \mathrm{C}$ or $41^{\circ} \mathrm{C}$ in differentiation medium containing final concentrations of $200 \mu \mathrm{g} / \mathrm{ml}$ or $400 \mu \mathrm{g} / \mathrm{ml}$ of the crude extract, $100 \mu \mathrm{g} / \mathrm{ml}$ of purified fraction, or $10 \mu \mathrm{g}$ $/ \mathrm{ml}$ of Con $\mathrm{A}$.

QM cells were seeded in plastic dishes coated with collagen and cultured at $37^{\circ} \mathrm{C}$. QM cells fuse more slowly than QMRSV cells and myotubes are formed within $72 \mathrm{hr}$ after change of differentiation medium $(8,9)$.

MDCK and HeLa cells were cultured in minimum essential medium (MEM) containing penicillin (100 units/ml), streptomycin $(0.1 \mathrm{mg} / \mathrm{ml})$, and $10 \%$ calf serum (CS). These cells were treated with the crude extract of silkworm faeces in the same way as QM-RSV cells.

Purification of the active substance. Dried silkworm faeces were a gift from Nagano Sericultural Laboratory (Nagano, Japan). An extract of the faeces was prepared as follows. A sample of $100 \mathrm{~g}$ of faeces was mixed with 10 volumes of phosphate-buffered saline (PBS(-); $\mathrm{NaCl} 8 \mathrm{~g} / 1, \mathrm{KCl} 0.2 \mathrm{~g} / 1$, $\left.\mathrm{Na}_{2} \mathrm{HPO}_{4} \cdot 12 \mathrm{H}_{2} \mathrm{O} 2.9 \mathrm{~g} / \mathrm{l}, \mathrm{KH}_{2} \mathrm{PO}_{4} 0.2 \mathrm{~g} / \mathrm{l}\right)$ and kept at $60^{\circ} \mathrm{C}$ overnight with occasional stirring. The mixture was then filtered through gauze, and the filtrate was centrifuged at $10^{4} \times \mathrm{g}$ for $15 \mathrm{~min}$. The supernatant was brought to $50 \%$ saturation of solid ammonium sulfate and allowed to stand for $1 \mathrm{hr}$ at $4^{\circ} \mathrm{C}$. It was then centrifuged at $10^{4} \times \mathrm{g}$ for $15 \mathrm{~min}$ at $4^{\circ} \mathrm{C}$ and the precipitate was dissolved in a suitable volume of $\operatorname{PBS}(-)$, dialyzed against $\mathrm{PBS}(-)$ for 3 days, lyophilized and stored at $-20^{\circ} \mathrm{C}$.

Isoelectric precipitation was performed as follows. The $50 \%$ ammonium sulfate precipitate was dissolved in distilled water at a concentration of $10 \mathrm{mg} / \mathrm{ml}, \mathrm{pH}$ adjusted to 3.5 by addition of $0.5 \mathrm{M}$ acetic acid in an ice bath, and allowed to stand for $1 \mathrm{hr}$ at $4^{\circ} \mathrm{C}$. It was then centrifuged at $10^{4} \times \mathrm{g}$ for 15 min at $4^{\circ} \mathrm{C}$ and the pellet was dissolved in a suitable volume of PBS $(-)$ by increasing the $\mathrm{pH}$ to 7.0 .

Reverse-phase HPLC was performed using a U6K pump, $600 \mathrm{E}$ system controller, 484 tunable absorbance detector, 741 data module (Waters Chromatography, Japan Millipore, Tokyo, Japan), and Model 201 fraction collector (Gilson Medical Electronics, WI, USA). A Protein $\mathrm{C}_{4}$ column (VYDAC, Separation Group, CA, USA, $10 \mathrm{~mm} \times 25 \mathrm{~cm}$ ) was used and the flow rate was $3 \mathrm{ml} / \mathrm{min}$. Samples were separated with a stepwise acetonitrile gradient, $(0-20 \mathrm{~min}, 10 \% ; 20-30 \mathrm{~min}$, $30 \% ; 30-45 \mathrm{~min}, 50 \%$ ). Protein peaks were detected by monitoring absorbance at $280 \mathrm{~nm}$.

For the extraction of the purified protein, the gel containing the protein was cut out by comparison of $\mathrm{Rf}$ value from the top with a stained fragment of the gel and lyophilized. Distilled water was added to the gel broken into pieces and allowed to stand at room temperature for a few hours. The extract was mixed with SM-2 beads (Bio Rad Laboratories, CA, USA) overnight at $4^{\circ} \mathrm{C}$ to remove SDS and concentrated by ultrafiltration (YM5, Diaflo Ultrafilter, Amicon Co., MA, USA).

The protein concentration of the purified fraction was measured by the method of Lowry et al. (11).

For treatment of the active substance with pronase E, pronase E (Sigma Chemical Co., St. Louis, USA) was added to the "NUE" fraction ( $1: 1$, weight/weight) and the mixture was incubated for $1 \mathrm{hr}$ at $37^{\circ} \mathrm{C}$. Trichloroacetic acid was added at a final concentration of $1 \%$ to terminate the reaction, and $\mathrm{pH}$ was returned to 7.0 by $1 \mathrm{~N} \mathrm{NaOH}$.

SDS-polyacrylamide gel electrophoresis analysis. SDSpolyacrylamide gel electrophoresis (SDS-PAGE) was described by Laemmli (10). Samples were separated in $12.5 \%$ polyacrylamide gel at constant current of $20 \mathrm{~mA}$. The proteins in the gel were stained with Coomassie Brilliant Blue $\mathrm{R}$ 250, and destained.

Oil Red O staining was performed by the method of Chin et al. (2). Isoelectric point was determined by using Phast Gel IEF 4-6.5 of the Phast System (Pharmacia LKB Biotechnology, Sweden).

Lectin blotting. After SDS-PAGE, the gel equilibrated in transfer buffer $(0.1 \mathrm{M}$ Tris, $0.192 \mathrm{M}$ glycine, and $20 \%$ methanol) was blotted onto nitrocellulose paper at $50 \mathrm{~mA}$ for $2 \mathrm{hr}$. The paper was treated with $25 \mathrm{mM} \mathrm{H}_{2} \mathrm{SO}_{4}$ at $80^{\circ} \mathrm{C}$ for $1 \mathrm{hr}$, and treated with horseradish peroxidase-conjugated lectin (concanavalin $\mathrm{A}$, Con $\mathrm{A}$; wheat germ agglutinin, WGA; or Phaseolus vulgaris lectin, E-PHA: Honen Co., Tokyo, Japan) in $\mathrm{T}$ buffer $(10 \mathrm{mM}$ Tris- $\mathrm{HCl} \mathrm{pH} \mathrm{7.4,0.05 \%} \mathrm{Tween}$ $20,0.15 \mathrm{M} \mathrm{NaCl}$ ) at $4^{\circ} \mathrm{C}$ for $1 \mathrm{hr}$. Then reactive glycoproteins were located with 4-chloro-1-naphthol and $\mathrm{H}_{2} \mathrm{O}_{2}$.

Assay of cell aggregation. QM-RSV cells were seeded at a density of $1.6 \times 10^{6}$ cells per 100 -mm-diameter, collagen -coated dish in $5 \mathrm{ml}$ of growth medium and precultured at 
$35.5^{\circ} \mathrm{C}$ for $24 \mathrm{hr}$. The cells were treated with $0.02 \%$ ethylenediaminetetraacetic acid (EDTA) and collected by pipetting. They were then washed with PBS $(-)$, and suspended at $5 \times$ $10^{6}$ cells per $\mathrm{ml}$ in PBS $(-)$. The purified active substance, or crude extract of silkworm faeces, was added to $0.5 \mathrm{ml}$ of cell suspension at a final concentration of $200 \mu \mathrm{g} / \mathrm{ml}$. The cell suspension was allowed to stand for $15 \mathrm{~min}$ in an ice bath, and then shaken 100 times/min at $35.5^{\circ} \mathrm{C}$ (PERSONAL-10 incubator, TAITEC, Tokyo, Japan). Aliquots were taken after shaking for $5,10,15$, and 30 min, diluted 5 times with $\operatorname{PBS}(-)$, put on Fuchs-Rosenthal titer plates and photographed for calculation of aggregation. Percentage of aggregation was calculated as $\{1-$ (Number of cell clusters + Number of cells not in clusters)/Total cell number $\} \times 100$.

When QM-RSV cells cultured at $41^{\circ} \mathrm{C}$ were used, cells were precultured at $35.5^{\circ} \mathrm{C}$ for $24 \mathrm{hr}$, the medium was changed to differentiation medium, and cultured at $41^{\circ} \mathrm{C}$ or at $35.5^{\circ} \mathrm{C}$ as a control for $6 \mathrm{hr}$. Cell aggregation was examined at $41^{\circ} \mathrm{C}$, or at $35.5^{\circ} \mathrm{C}$ as a control.

For treatment with tunicamycin, QM-RSV cells were precultured as described above and cultured at $35.5^{\circ} \mathrm{C}$ for $18 \mathrm{hr}$ in differentiation medium containing tunicamycin (Sigma Chemical Co., St. Louis, USA) at a final concentration of $1 \mu \mathrm{g} / \mathrm{ml}$. Aggregation of these cells was examined as described above.

For examination of the effect of sugars on the aggregation reaction, various sugars (glucose, galactose, $\mathrm{D}-(+)$-fucose, $\mathrm{N}$ acetyl-D-galactosamine, $\mathrm{N}$-acetyl-D-glucosamine, $\alpha$-D-methyl mannoside, $\mathrm{N}$-acetyl neuraminic acid) were added to the reaction mixture at final concentrations of $5 \mathrm{mM}$.

For examination of the effects of glycoletherdiaminetetraacetic acid (EGTA) on the aggregation reaction, EGTA was added to the cell suspension at a final concentration of $1 \mathrm{mM}$.

HeLa and MDCK cells were seeded at densities of $3 \times 10^{6}$ cells per 100 -mm-diameter glass dish and cultured at $37^{\circ} \mathrm{C}$ for $24 \mathrm{hr}$. They were then collected by treatment with $0.25 \%$ trypsin and $0.02 \%$ EDTA $(1: 1)$, and their aggregation was examined on treatment with the extract of silkworm faeces at $37^{\circ} \mathrm{C}$ for $10 \mathrm{~min}$ as described above.

ETC, B cells, and T cells were washed with PBS( - ) before examination of their aggregation by the extract of silkworm faeces at $37^{\circ} \mathrm{C}$ for $10 \mathrm{~min}$ as described above. C-RBC were washed with $\mathrm{PBS}(-)$ and tested for aggregation at $37^{\circ} \mathrm{C}$ for $10 \mathrm{~min}$ as described above using $200 \mu \mathrm{g} / \mathrm{ml}, 400 \mu \mathrm{g} / \mathrm{ml}$, or $800 \mu \mathrm{g} / \mathrm{ml}$ of the extract.

Binding assay of purified substance. The purified active substance was labeled with $\left[{ }^{3} \mathrm{H}\right]$-acetic anhydride (NEN Research Products, Boston, USA) by the method of Kagawa (7).

For binding assay of a tritium-labeled active substance, a suspension of QM-RSV cells was prepared as described in "Assay of Cell Aggregation" and $5 \times 10^{4} \mathrm{cpm}$ of labeled active substance was added. The mixture was shaken in an ice bath, or at $35.5^{\circ} \mathrm{C}$, or $41^{\circ} \mathrm{C}$ for $15 \mathrm{~min}$, and then the cells were washed with $\mathrm{PBS}(-)$ three times and solubilized in $0.1 \%$ SDS. Proteins were precipitated from this solution with an equal volume of solution containing $10 \%$ trichloroacetic acid and $2 \%$
Nonidet $\mathrm{P}-40$, and radioactivity was counted in a liquid scintillation counter (LS 5000TA, Beckman, CA, USA). Binding of the active substance is expressed as cpm per $10^{6}$ cells.

\section{RESULTS}

Biological activities of silkworm faeces extract of $Q M-R S V$ cells. We examined the effects of the crude extract of silkworm faeces on contraction of myocardiac cells, cell growth, and differentiation of QM-RSV cells. Its only marked effect was on QM-RSV cells.

QM-RSV cells proliferate at $35.5^{\circ} \mathrm{C}$, the permissive temperature for RSV, but do not differentiate, whereas, at $41^{\circ} \mathrm{C}$, a nonpermissive temperature for the virus, the cells begin to differentiate, fusing with each other, and forming multinucleated myotubes within about $24 \mathrm{hr}$ after the shift up to $41^{\circ} \mathrm{C}$. Namely, differentiation of QM-RSV cells is controlled by temperature. These phenomena are associated with the protein kinase activity of the src gene product of the virus used for cell transformation $(8,9)$.

Unique activity was recognized in QM-RSV cells treated with the extract of silkworm faeces. QM-RSV cells were seeded and precultured at $35.5^{\circ} \mathrm{C}$ for $24 \mathrm{hr}$ as described in "Materials and Methods." In this condition, the cells adhere to the dishes and proliferate to cell confluency (Fig. 1a). These plated cells were incubated with a crude extract of silkworm faeces at a final concentration of $200 \mu \mathrm{g} / \mathrm{ml}$ at $35.5^{\circ} \mathrm{C}$ or $41^{\circ} \mathrm{C}$. As shown in Fig. 1b, QM-RSV cells cultured at $35.5^{\circ} \mathrm{C}$ began to detach from the dishes in $3 \mathrm{hr}$ and the detached cells aggregated. On further incubation, cell detachment proceeded and most cells were detached and aggregated in $6 \mathrm{hr}$ after addition of the extract (Fig. 1c). When the cells detached at $35.5^{\circ} \mathrm{C}$, shown in Fig. 1c, were collected and reseeded after washing, they adhered normally to dishes at $35.5^{\circ} \mathrm{C}$ and $41^{\circ} \mathrm{C}$, suggesting that the effect of the extract was not lethal (data not shown).

In contrast to results at $35.5^{\circ} \mathrm{C}$, no induction of cell detachment by the extract was recognized in cultures at $41^{\circ} \mathrm{C}$ even after $10 \mathrm{hr}$ (Fig. 1d), myotubes being formed until $24 \mathrm{hr}$ (Fig. 1e) as in control culture. Although some cells appear spherical after $24 \mathrm{hr}$, these were clear differences between the appearance of cells at $35.5^{\circ} \mathrm{C}$ and $41^{\circ} \mathrm{C}$ treated with the extract.

When the concentration of the extract of silkworm faeces was increased to $400 \mu \mathrm{g} / \mathrm{ml}$, cells became detached from the dishes and aggregated even at $41^{\circ} \mathrm{C}$. These detached cells did not adhere to dishes when they were reseeded after washing, suggesting that the effect of the extract was lethal (data not shown).

Plated MDCK and HeLa cells were also not detached by treatment with the extract at either $200 \mu \mathrm{g} / \mathrm{ml}$ or 400 $\mu \mathrm{g} / \mathrm{ml}$ (Fig. 1f). Thus, the effect of the extract in causing cell detachment seemed to be specific to QM-RSV 

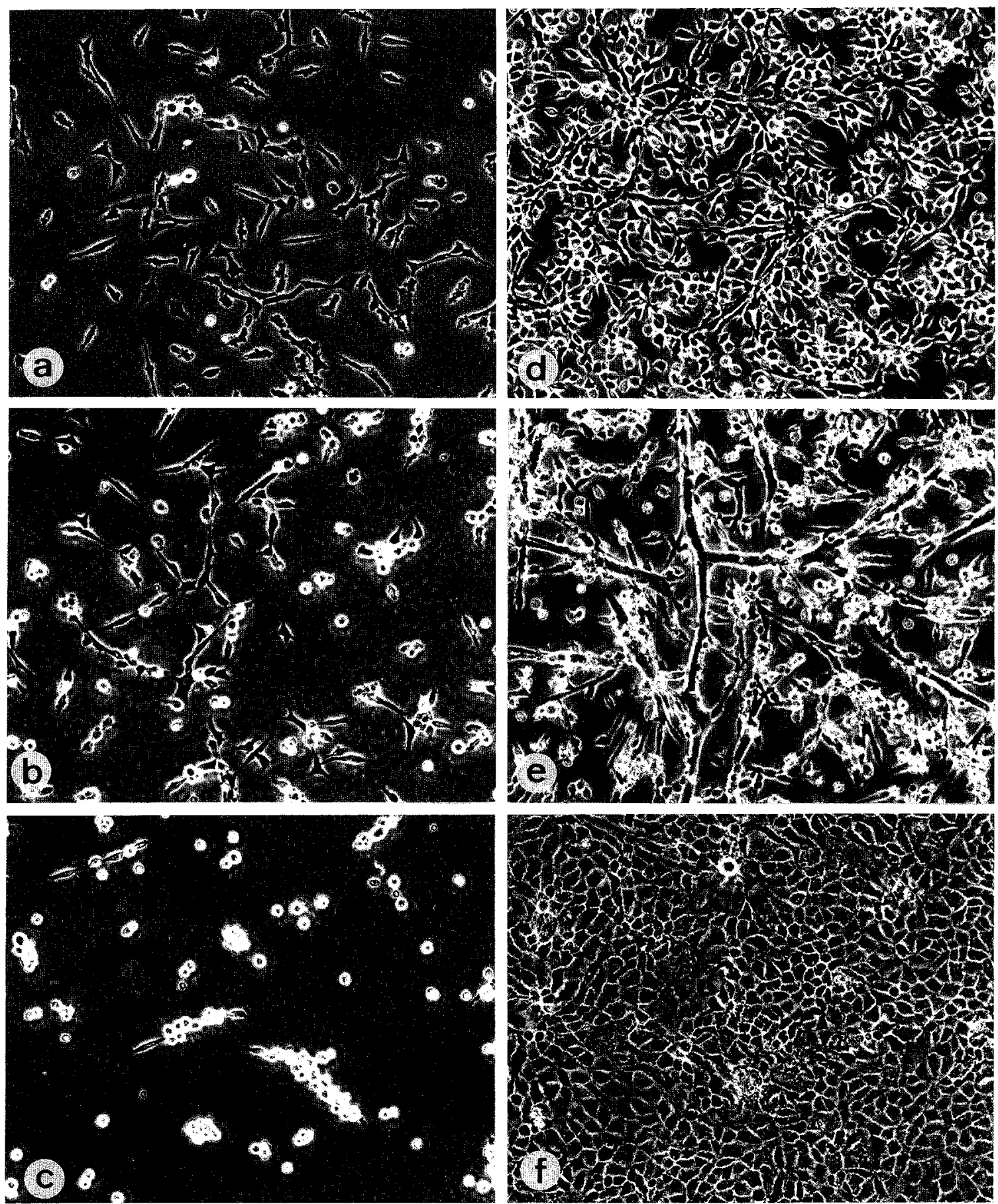

Fig. 1. Effect of the extract of silkworm faeces of QM-RSV and MDCK cells.

QM-RSV cells were seeded at a density of $2 \times 10^{5}$ cells per $2 \mathrm{ml}$ of growth medium in 35 -mm-diameter collagen-coated dishes and precultured at $35.5^{\circ} \mathrm{C}$ for $24 \mathrm{hr}$. Then the extract of silkworm faeces was added at a final concentration of $200 \mu \mathrm{g} / \mathrm{ml}$ in defferentiation medium and cells were cultured at $35.5^{\circ} \mathrm{C}$ or $41^{\circ} \mathrm{C}$. a) QM-RSV cells before addition of the extract of silkworm faeces. b) QM-RSV cells cultured at $35.5^{\circ} \mathrm{C}$ for $3 \mathrm{hr}$ after addition of the extract. Cells are beginning to detach from the dish. c) QM-RSV cells cultured at $35.5^{\circ} \mathrm{C}$ for $6 \mathrm{hr}$ after addition of the extract. Most cells are detached and aggregated. d) QM-RSV cells cultured at $41^{\circ} \mathrm{C}$ for $10 \mathrm{hr}$ in the presence of the extract of silkworm faeces. Cells are not detached from the dish, unlike at $35.5^{\circ} \mathrm{C}$. e) QM-RSV cells cultured at $41^{\circ} \mathrm{C}$ for $24 \mathrm{hr}$ after addition of the extract. Myotubes are formed as in untreated cultures, but some remaining monocytes are detached. f) MDCK cells cultured for $24 \mathrm{hr}$ after addition of the extract at a final concentration of $400 \mu \mathrm{g} / \mathrm{ml}$. Cells are not detached. Magnification, $\times 100$. 


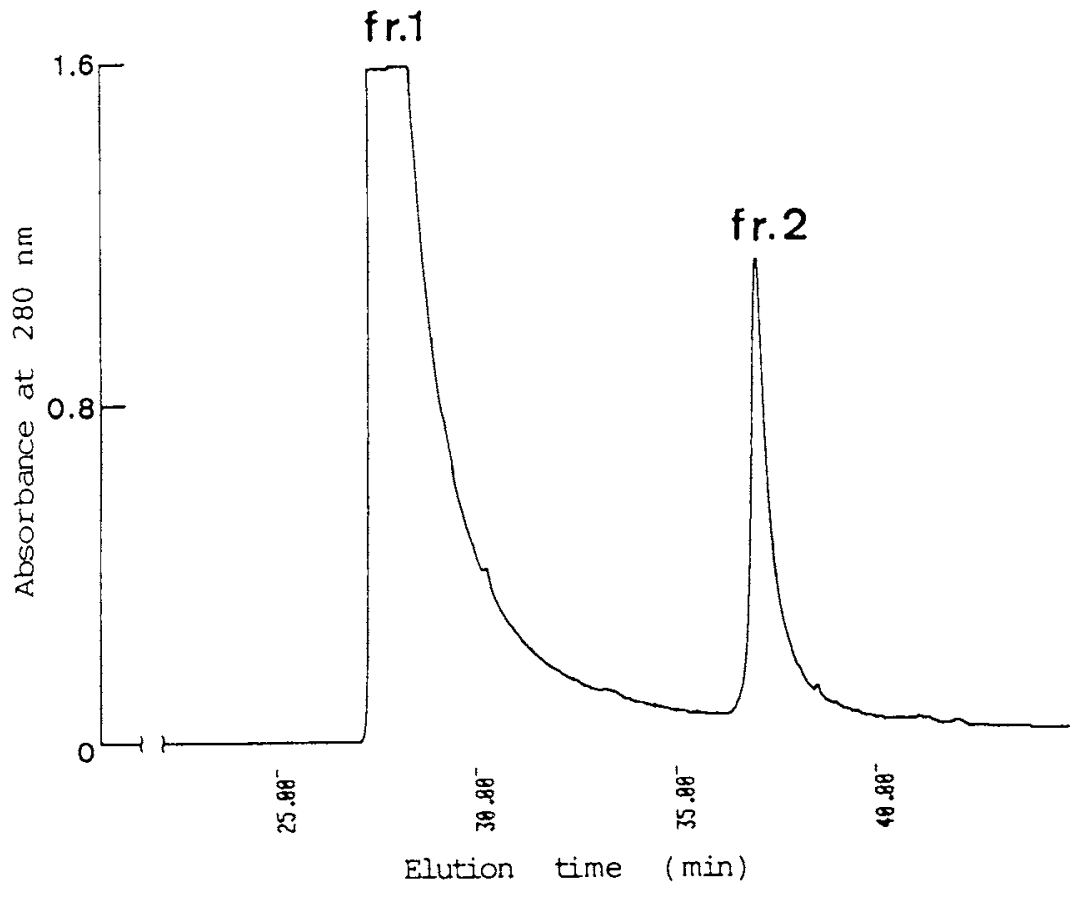

Fig. 2. Profile of chromatograph by reverse-phase HPLC.

The isoelectric precipitate was applied to the $\mathrm{C}_{4}$ protein column and two peaks, fraction 1 and 2 , were obtained. Cell aggregation activity was detected in fraction 1, named the "NUE" fraction.

cells cultured at $35.5^{\circ} \mathrm{C}$.

Purification of the active substance. Next, we purified the active substance in the extract of silkworm faeces by monitoring its effect on cell aggregation .

Precipitate with 50\% ammonium sulfate described above was dissolved in distilled water and $\mathrm{pH}$ adjusted to 3.5 with acetic acid. The resulting precipitate was collected by centrifugation and dissolved in a suitable volume of PBS(-) by increasing the $\mathrm{pH}$ to 7.0.

Further purification was achieved by reverse-phase HPLC. For this, the material obtained by isoelectric precipitation was applied to a $\mathrm{C}_{4}$ column equilibrated with distilled water containing $0.1 \%$ trifluoroacetic acid and eluted with a stepwise acetonitrile gradient. As shown in Fig. 2, two peaks (fractions 1 and 2) were obtained. Fraction 1 had aggregation activity, whereas, fraction 2 did not. Fraction 1 was named the "NUE" fraction, because "NUE" means silkworm in Korean, and its biochemical and biological characteristics were examined.

Biochemical characterization of the "NUE" fraction. SDS-PAGE analysis of each fraction was shown in Fig. 3 . The $50 \%$ ammonium sulfate precipitate and isoelectric precipitate all gave several bands (Fig. 3, lanes 2, 3, $5,6)$. On the other hand, under nonreduced conditions, the "NUE" fraction (fraction 1) gave one broad band of about $60 \mathrm{kDa}$ (Fig. 3, lane 1) detected by Coomassie Brilliant Blue staining. This substance had maximum ab- sorbance at $230 \mathrm{~nm}$, suggesting that the "NUE" fraction does not consist of a simple protein. Under reduced conditions, a doublet around $50 \mathrm{kDa}$ and another doublet about $17 \mathrm{kDa}$ were detected, suggesting some destruction of the molecule (Fig. 3, lane 4).

The results of SDS-PAGE analysis and the maximum absorbance of the "NUE" fraction suggested that this fraction contains sugars or lipids. After SDS-PAGE of the "NUE" fraction, no lipids were detected by staining with Oil Red O. For detection of the sugar, lectin blotting was performed with Con A-peroxidase reagent. The "NUE" fraction was recognized under nonreduced conditions (Fig. 4, lane 1). Similar results were obtained with WGA- and E-PHA-peroxidase reagent (data not shown). These results indicate that this substance is a glycoprotein. Under reduced conditions, no sugars were recognized (Fig. 4, lane 2), suggesting that in these conditions, sugar chains were cut off. The isoelectric point of the "NUE" fraction was about 4.8 as judged with a Phast System.

No other bands were detected besides the $60 \mathrm{kDa}$ protein on SDS-PAGE analysis (Fig. 3, lane 1), suggesting that the "NUE" fraction was that of an almost isolated glycoprotein, although its band was broad. To confirm that this $60 \mathrm{kDa}$ protein really has the cell detachment and aggregation activity shown in Fig. 1, this protein was extracted from the gel and its activity examined. 
E. Hirayama et al.

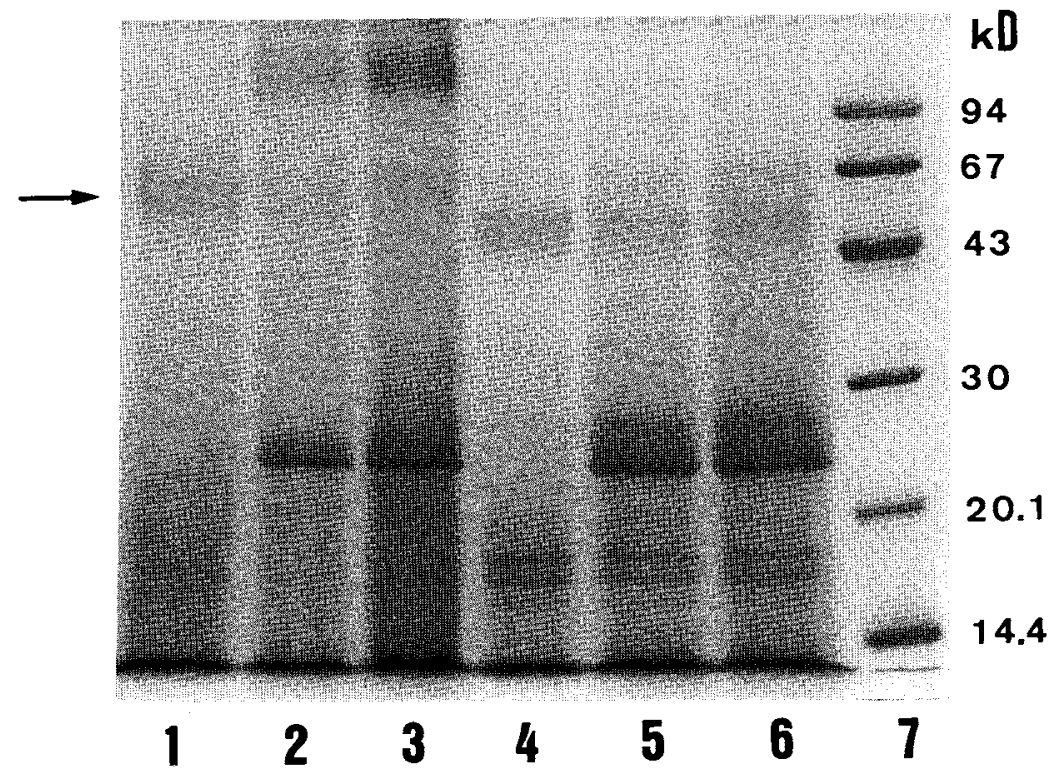

Fig. 3. SDS-polyacrylamide gel electrophoresis analysis of purified fraction.

The fractions obtained during purification were applied to $12.5 \%$ polyacrylamide gel and the gel was stained with Coomassie Brilliant Blue R250 for proteins. Lane 1, HPLC fraction 1 ("NUE" fraction) under nonreduced conditions. Fraction 1 purified by reverse-phase HPLC shows one broad band (arrow). Lane 2, isoelectric precipitate under nonreduced conditions. Lane 3, precipitate with 50\% saturated ammonium sulfate under nonreduced conditions. Lane 4, HPLC fraction 1 ("NUE" fraction) under reduced conditions. Lane 5, isoelectric precipitate under reduced conditions. Lane 6 , precipitate with 50\% saturated ammonium sulfate under reduced conditions. Lane 7, molecular weight markers.

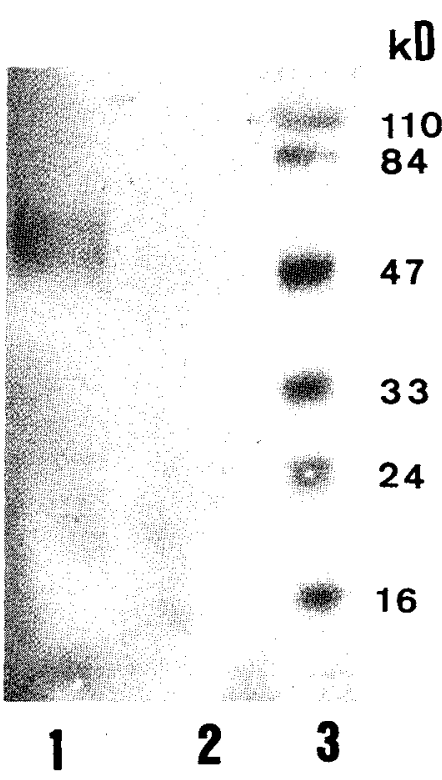

Fig. 4. Lectin blotting of the "NUE" fraction using concanavalin A. Fraction 1 ("NUE" fraction) was electrophoresed and then blotted with Con A-peroxidase reagent. Fraction 1 ("NUE" fraction) was recognized as a broad band with Con A-peroxidase reagent; however, under reduced conditions, it gave no distinct bands. Lane 1, fraction 1 ("NUE" fraction) under nonreduced conditions. Lane 2 , fraction 1 ("NUE" fraction) under reduced conditions. Lane 3, molecular weight markers.
The $60 \mathrm{kDa}$ protein was extracted from the gel with distilled water, and reelectrophoresed under reduced or nonreduced conditions to ascertain the extraction. The protein was confirmed to have a molecular mass of about $60 \mathrm{kDa}$ (Fig. 5A, lane 2), and it was suggested that a doublet around $50 \mathrm{kDa}$ and another doublet at about $17 \mathrm{kDa}$ under reduced conditions were derived from this $60 \mathrm{kDa}$ protein (Fig. 5A, lane 1). When plated QM-RSV cells were treated with the extract from the gel, the cells were detached from the dish and aggregated with each other as in the case of crude fraction (Fig. 5B, a). These results indicate that this $60 \mathrm{kDa}$ protein is the active substance.

The "NUE" fraction was relatively heat-stable, not losing activity upon heating at $70^{\circ} \mathrm{C}$ for $1 \mathrm{hr}$, but the activity disappeared on boiling at $100^{\circ} \mathrm{C}$ for $15 \mathrm{~min}$.

On treatment of the "NUE" fraction with pronase $\mathrm{E}$, its SDS-PAGE pattern changed and its activity was lost, suggesting that the protein part of the "NUE" fraction contains its active site.

Aggregation of QM-RSV cells by the "NUE" fraction. As described above, QM-RSV cells cultured at $35.5^{\circ} \mathrm{C}$ were detached from the dishes on incubation with the "NUE" fraction and most of the detached cells aggregated (Fig. 1c). We next examined whether or not QM-RSV cells in suspension are aggregated by the "NUE" fraction. QM-RSV cells precultured at $35.5^{\circ} \mathrm{C}$ for $24 \mathrm{hr}$ as described in "Materials and Methods" were 
treated with EDTA and suspended in $\operatorname{PBS}(-)$ after washing. Then the "NUE" fraction was added to the cell suspension at a final concentration of $200 \mu \mathrm{g} / \mathrm{ml}$ and after standing for $15 \mathrm{~min}$ in an ice bath, the suspension was shaken at $35.5^{\circ} \mathrm{C}$. Addition of the "NUE" fraction to the cell suspension at low temperature did not result in cell aggregation (Fig. 7, at 0 min of incubation time). On incubation at $35.5^{\circ} \mathrm{C}$, however, it induced cell aggregation within $5 \mathrm{~min}$ (Fig. 6b), and the extent of aggregation increased with the incubation time to a plateau at $30 \mathrm{~min}$ (Fig. 7). This aggregation was similar in the presence of $1 \mathrm{mM}$ EGTA, suggesting that cell aggregation was independent of $\mathrm{Ca}^{2+}$ ions.

The "NUE" fraction did not induce aggregation of
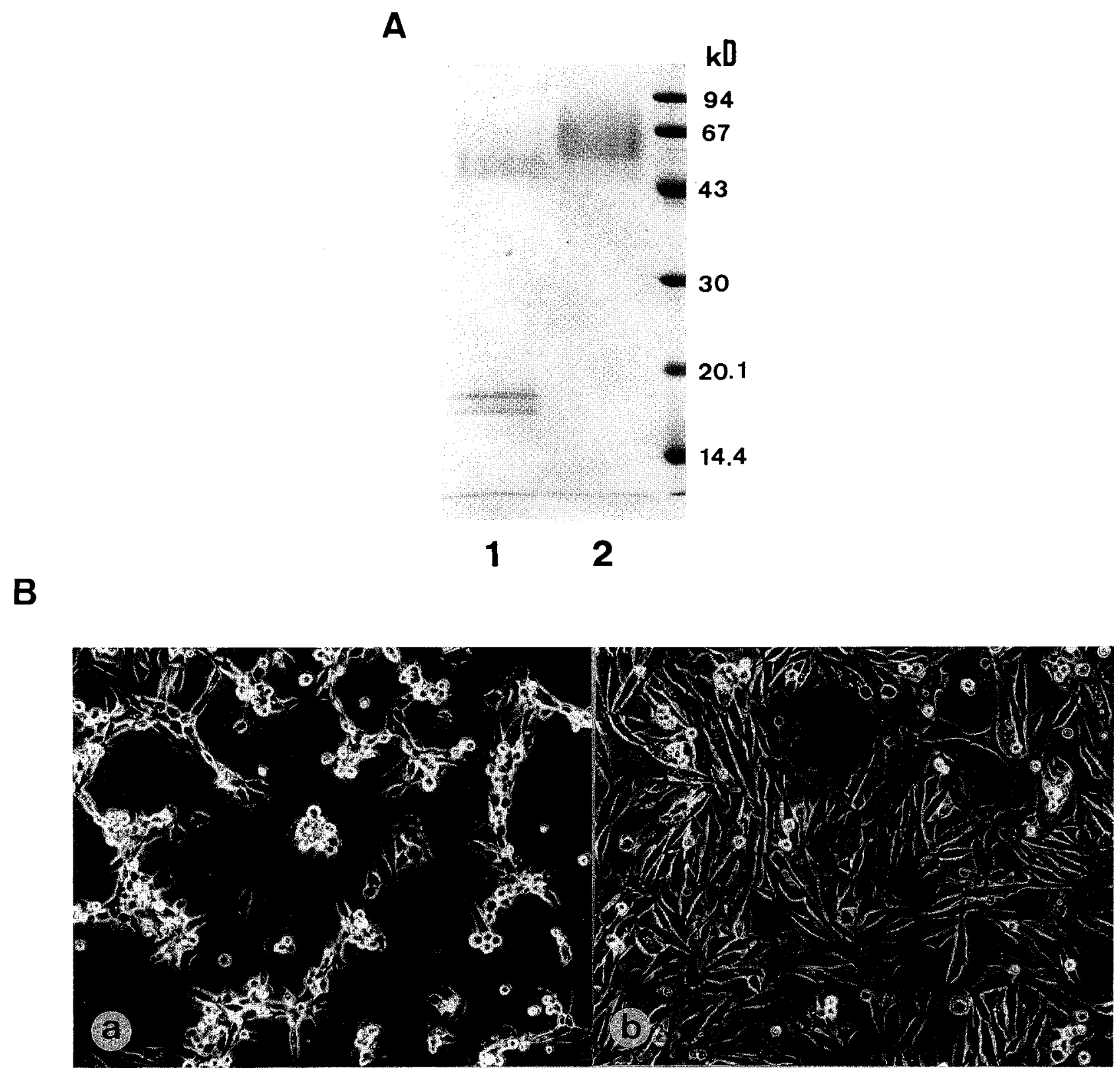

Fig. 5. Effects of the extract from $60 \mathrm{kDa}$ band to QM-RSV cells.

The $60 \mathrm{kDa}$ protein shown in fig. 3 (lane 1) was extracted from the gel, and QM-RSV cells were treated with the extract at a final concentration of $100 \mu \mathrm{g} / \mathrm{ml}$ for $6 \mathrm{hr}$ at $35.5^{\circ} \mathrm{C}$. A: SDS-PAGE of the $60 \mathrm{kDa}$ protein extracted from the gel. The $60 \mathrm{kDa}$ protein is clearly extracted from the gel (lane 2). Lane 1, the extract from the gel under reduced conditions. Lane 2, the extract from the gel under nonreduced conditions. B: a) QM-RSV cells treated with the extract from $60 \mathrm{kDa}$ band. Cells were detached and aggregated by the extract. b) QM-RSV cells untreated with the extract from the gel as a control. Cells attach to the dish. Magnification, $\times 100$. 

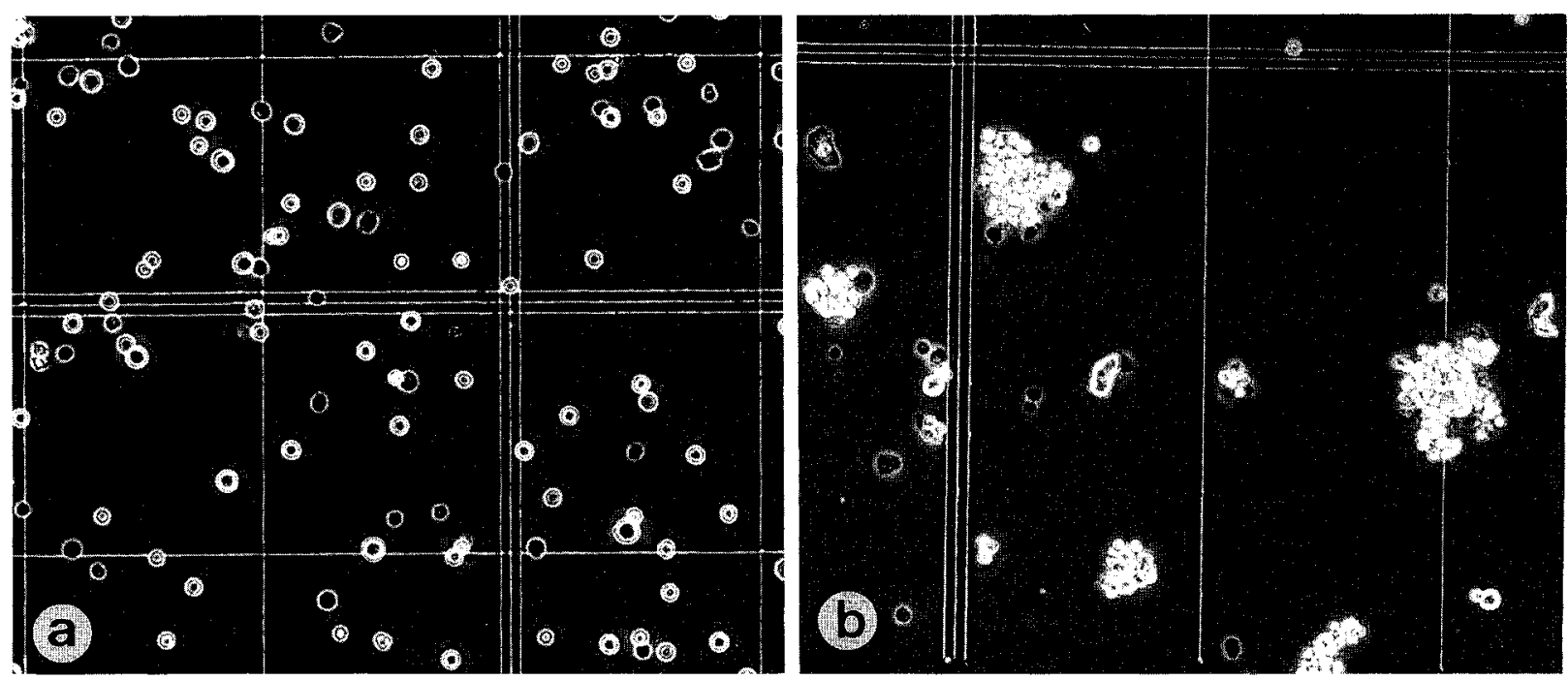

Fig. 6. Aggregation of QM-RSV cells in suspension by the "NUE" fraction.

QM-RSV cells cultured at $35.5^{\circ} \mathrm{C}$ for $24 \mathrm{hr}$ were treated with EDTA and suspended in PBS( - ) after washing. The "NUE" fraction was added to the cell suspension at a final concentration of $200 \mu \mathrm{g} / \mathrm{ml}$. The suspension was allowed to stand on ice for 15 min and then shaken at $35.5^{\circ} \mathrm{C}$ for $10 \mathrm{~min}$. a) Control: cell suspension without the "NUE" fraction. Cell aggregation is not observed. b) Cells incubated with the "NUE" fraction for $10 \mathrm{~min}$. Cell aggregation is observed. Magnification, $\times 100$.

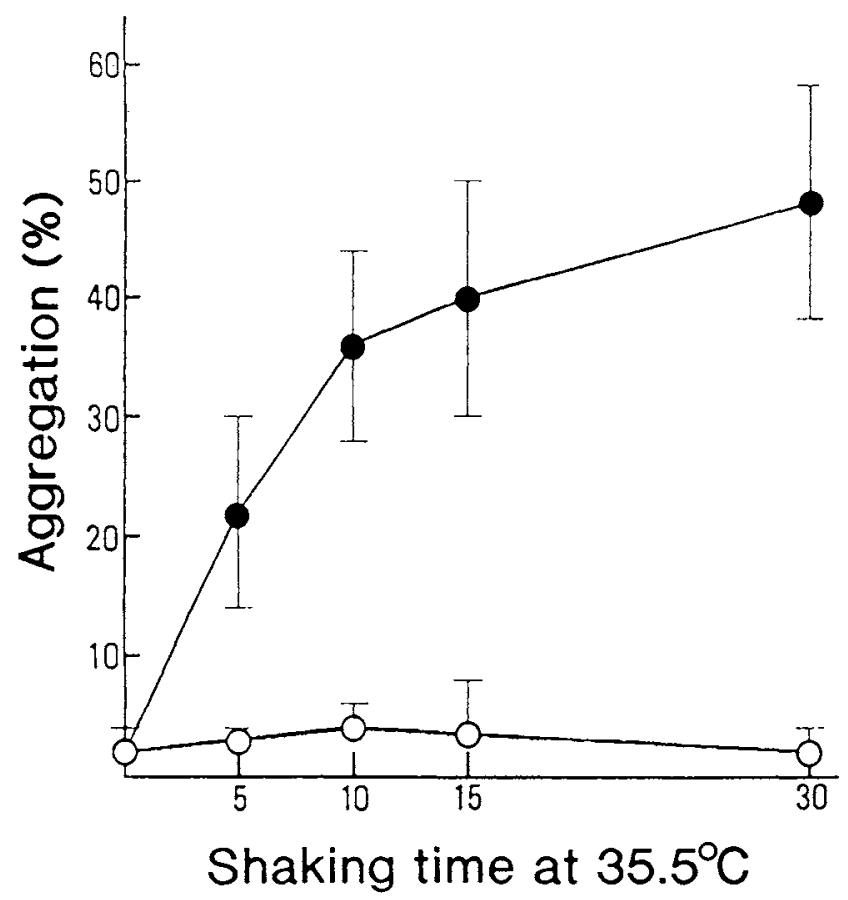

Fig. 7. Time course of change in cell aggregation.

A suspension of QM-RSV cells was prepared as for Fig. 5, and shaken with an extract of silkworm faeces at $35.5^{\circ} \mathrm{C}$. Aliquots of cells were taken after $5,10,15,30 \mathrm{~min}$, for measurement of the percentage of cell aggregation. At $0 \mathrm{~min}$ time, no cell aggregation was observed, even in the presence of the extract. but, cell aggregation occurred gradually on shaking at $35.5^{\circ} \mathrm{C}$. - - with the extract of silkworm faeces at a final concentration of $200 \mu \mathrm{g} / \mathrm{ml},-\mathrm{O}-$, control without the silkworm faeces extract. cells incubated in an ice bath. Namely, cell aggregation did not occur at low temperatures of near $0^{\circ} \mathrm{C}$. One possible reason for this phenomenon is that the "NUE" fraction cannot bind to cells at low temperature. To determine whether the "NUE" fraction can bind to cells at low temperature, we examined binding of the "NUE" fraction to the cells at $0^{\circ} \mathrm{C}$ using a tritium-labeled "NUE" fraction. The tritium-labeled "NUE" fraction was added to cell suspensions in an ice bath, and then the suspensions were shaken at $35.5^{\circ} \mathrm{C}$ or in the ice bath. The cells were then washed three times with PBS $(-)$, and solubilized in SDS, and the radioactivity bound to the cells was counted. The results in Table I show that the radioactivities in the two conditions were nearly the same, indicating that the "NUE" fraction can bind to cells irrespective of the temperature.

On the plated QM-RSV cells, when the cells were cultured at $41{ }^{\circ} \mathrm{C}$ with the "NUE" fraction, detachment and aggregation were not observed in contrast to the cells cultured at $35.5^{\circ} \mathrm{C}$ (Fig. 1c and d). This suggests that the number of binding sites of the "NUE" fraction

Table I. Binding of the tRITIUM-LABELED "NUE" fRACtion TO QM-RSV CELLS.

\begin{tabular}{lc}
\hline QM-RSV cells & cpm per $10^{6}$ cell $\left(\times 10^{3}\right)$ \\
\hline shaking in ice bath & $2.41 \pm 0.16$ \\
shaking at $35.5^{\circ} \mathrm{C}$ & $2.13 \pm 0.26$ \\
cultured at $35.5^{\circ} \mathrm{C}$ & $2.27 \pm 0.49$ \\
cultured at $41^{\circ} \mathrm{C}$ & $2.42 \pm 0.18$ \\
\hline
\end{tabular}


Table II. Aggregation of Various cells by the extract OF SILKWORM FAECES.

\begin{tabular}{|c|c|}
\hline cells & aggregation at $10 \mathrm{~min}$ \\
\hline QM-RSV & ++ \\
\hline primary QM & ++ \\
\hline MDCK & + \\
\hline Hela & + \\
\hline mouse B cells & ++ \\
\hline mouse $T$ cells & $+t$ \\
\hline ETC & ++ \\
\hline C-RBC $\quad 200 \mu \mathrm{g} / \mathrm{ml}$ & - \\
\hline $400 \mu \mathrm{g} / \mathrm{ml}$ & - \\
\hline $800 \mu \mathrm{g} / \mathrm{ml}$ & + \\
\hline
\end{tabular}

,+++ , and $-:$ degrees of aggregation $(++>+>-)$ at 200 $\mu \mathrm{g} / \mathrm{ml}$.

on cell surfaces differ between incubations at $35.5^{\circ} \mathrm{C}$ and $41^{\circ} \mathrm{C}$. Therefore, binding assay using the tritium-labeled "NUE" fraction was also performed on the QMRSV cells cultured at $35.5^{\circ} \mathrm{C}$ and $41^{\circ} \mathrm{C}$ in suspension. However, as shown in Table $\mathrm{I}$, no difference was detected between the cells cultured at $35.5^{\circ} \mathrm{C}$ and $41^{\circ} \mathrm{C}$.

The aggregation of other cells was examined in the same manner (Table II). Primary quail myoblast (QM) cells, ETC, mouse B cells, and T cells were aggregated to the same extent as QM-RSV cells. QM-RSV cells cultured at $41^{\circ} \mathrm{C}, \mathrm{MDCK}$, and $\mathrm{HeLa}$ cells in suspension were also aggregated, in contrast to plated cells, which were not detached by the "NUE" fraction as described above. C-RBC cells showed somewhat weak aggrega- tion, but, at high concentration of the "NUE" fraction, they also showed aggregation .

The "NUE" fraction is a kind of lectin. Since the "NUE" fraction has aggregation activity, it is assumed that it is a kind of lectin. To confirm this point, QMRSV cells were treated with tunicamycin, which inhibits the early stage of glycosylation $(5,15)$, and then their aggregation by the "NUE" fraction was examined. For this, QM-RSV cells were cultured with $1 \mu \mathrm{g} / \mathrm{ml}$ tunicamycin for $18 \mathrm{hr}$, before the aggregation reaction. It was confirmed that glycosylation was inhibited by tunicamycin treatment. On treatment with tunicamycin, the aggregation activity was almost completely attenuated compared with that of control cells (Fig. 8). This result suggests that the binding sites of the "NUE" traction are sugar chains on the cell surface. Thus, it was demonstrated that the "NUE" fraction is a kind of lectin.

We examined the sugar recognized by the "NUE" fraction by tests of inhibition of aggregation of QMRSV cells in the presence of various sugars. As shown in Table III, of the sugars examined, only $\alpha$-D-methyl mannoside inhibited the aggregation activity of the "NUE" fraction. This result suggests that the "NUE" fraction is a lectin-recognizing mannose on the cell surface.

Con $\mathrm{A}$ is well known as a lectin which binds to $\alpha$-Dmethyl mannoside. It was thus examined whether Con A also exhibits cell detachment activity. When Con A was added to plated QM-RSV cells and cultured at $35.5^{\circ} \mathrm{C}$ or $41^{\circ} \mathrm{C}$, detachment and aggregation of the cells occur, as in the "NUE" fraction at both temperatures (data not shown). However, no difference in the ac-
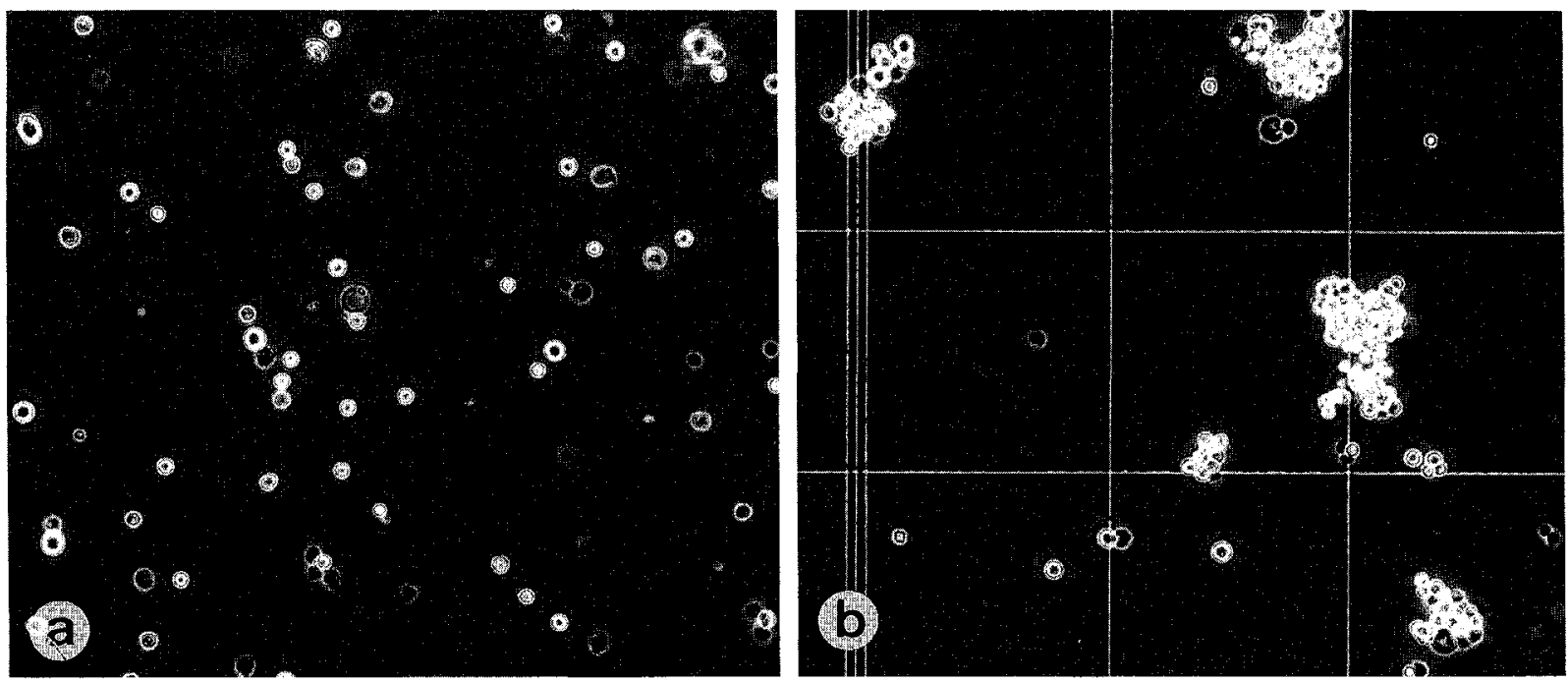

Fig. 8. Aggregation by the "NUE" fraction of QM-RSV cells treated with tunicamycin.

QM-RSV cells precultured as for Fig. 5 were treated with tunicamycin at a final concentration of $1 \mu \mathrm{g} / \mathrm{ml}$ for $18 \mathrm{hr}$ at $35.5^{\circ} \mathrm{C}$. Then a cell suspension was prepared as for Fig. 5 and incubated with the "NUE" fraction. Cell aggregation was almost completely attenuated in cells treated with tunicamycin. a) Aggregation of QM-RSV cells treated with tunicamycin and the "NUE" fraction, b) Control, QM-RSV cells not treated with tunicamycin. Magnification, $\times 100$. 
Table III. INHIBITIONS OF CELI AGGREGATION BY VARIOUS SUGARS.

\begin{tabular}{lc}
\hline sugar & inhibition of aggregation \\
\hline$\alpha$-D-methylmannoside & + \\
N-acetyl-D-galactosamine & - \\
galactose & - \\
N-acetyl-D-glucosamine & - \\
glucose & - \\
D-(+)-fucose & - \\
N-acetylneuraminic acid & - \\
\hline
\end{tabular}

Aggregation by the "NUE" fraction was assayed using QM-RSV cells as for Fig. 5 in the presence of each sugar. Inhibition of aggregation was judged after $10 \mathrm{~min}$ of incubation.

tivities between incubations at $35.5^{\circ} \mathrm{C}$ and $41^{\circ} \mathrm{C}$ was observed in Con $\mathrm{A}$, unlike the "NUE" fraction, suggesting that the "NUE" fraction distinguishes some differences in QM-RSV cells between incubations at $35.5^{\circ} \mathrm{C}$ and $41^{\circ} \mathrm{C}$, and its binding sites are not same as those of Con A.

\section{DISCUSSION}

In this study, we isolated a lectinlike, biologically active substance from an extract of silkworm faeces purified lectinlike substance is a glycoprotein with an apparent molecular mass of about $60 \mathrm{kDa}$ as judged by SDSPAGE analysis and lectin blotting. We named this substance the "NUE" fraction. From studies on cells treated with tunicamycin, it was indicated that the "NUE" fraction recognizes the sugar on the cell surface, suggesting that it is a lectinlike substance. Furthermore, mannose was a prominent candidate for the cell surface epitope detected by the "NUE" fraction.

The "NUE" fraction has a unique action on QM-RSV cells. When it was added to plated QM-RSV cells cultured at $35.5^{\circ} \mathrm{C}$ (the permissive temperature for RSV), it caused detachment and aggregation of the cells. However, in cultures at $41^{\circ} \mathrm{C}$ (a nonpermissive temperature for the virus), the same dose of the "NUE" fraction did not cause cell detachment or inhibit myoblast fusion. Noonan et al. also reported that with cells transformed by a temperature-sensitive oncovirus, cell aggregation is increased by Con $\mathrm{A}$ at a permissive temperature, but not at a nonpermissive temperature (12). These results obviously suggest that the surface structures of QMRSV cells have different characteristics upon incubation at $35.5^{\circ} \mathrm{C}$ and $41^{\circ} \mathrm{C}$. The number of binding sites of the "NUE" fraction was not changed between the cells cultured at $35.5^{\circ} \mathrm{C}$ and $41^{\circ} \mathrm{C}$ in suspension state, there are distinct differences in the plated state between the cells cultured at $35.5^{\circ} \mathrm{C}$ and $41^{\circ} \mathrm{C}$. It is demonstrated that cell-substratum attachment is qualitatively different from cell-cell adhesion. In the plated cells, it is suggested that the number of binding sites of the "NUE" fraction may decrease, some conformational changes occur at binding sites by transformation at $35.5^{\circ} \mathrm{C}$, or a possibility of other components that accelerate or suppress the detachment should be considered. These differences at the two temperatures may also be related to the differentiation of QM-RSV cells or transformation of the cells. Defining the differences in QM-RSV cells incubated at $35.5^{\circ} \mathrm{C}$ and $41^{\circ} \mathrm{C}$ using the "NUE" fraction will be very effective in analysis of the differentiation of QM-RSV cells.

Like the plated cells, QM-RSV cells in suspension show aggregation. This cell aggregation was observed at $35.5^{\circ} \mathrm{C}$, but not at about $0^{\circ} \mathrm{C}$ : shaking at $35.5^{\circ} \mathrm{C}$ is required for cell aggregation. Binding assays showed that the "NUE" fraction bound to cells irrespective of the incubation temperature. Therefore, either the fluidity of cell membrane may decrease at low temperature with consequent decrease of mediation of binding of cells by the "NUE" fraction, even though the "NUE" fraction can bind to the membrane surface, or, if cell aggregation occurs only when clusters of receptors are formed, this clustering of receptors may be inhibited at low temperature. Rosenblith et al. have reported that clustering of lectin receptors does not occur at low temperature (14).

Of the cells examined, only plated QM-RSV cells cultured at $35.5^{\circ} \mathrm{C}$ were detached from the dishes by the "NUE" fraction, although plated QM-RSV cells cultured at $41^{\circ} \mathrm{C}$ were also detached from dishes by the "NUE" fraction at high concentration. In contrast, plated MDCK and HeLa cells were not detached by this fraction. This result suggests that membrane surfaces of QM-RSV cells cultured at $35.5^{\circ} \mathrm{C}$ have different characteristics from those of cells cultured at $41^{\circ} \mathrm{C}$ and other kinds of cells. Namely, QM-RSV cells cultured at $35.5^{\circ} \mathrm{C}$ are more sensitive to the "NUE" fraction or attach to the substratum more loosely than the other cells. It is well known that transformation with RSV induces loss of cell adhesion, including disruption of adhesion plaques and destruction of stress fibers $(4,13)$. Therefore, detachment of plated QM-RSV cells cultured at $35.5^{\circ} \mathrm{C}$ may be related to transformation, or to the differences in cell surfaces at $41^{\circ} \mathrm{C}$ due to differentiation. In contrast to the phenomenon of cell detachment, all the cells examined were aggregated in suspension by treatment with the "NUE" fraction, and further, the binding assay showed that the amount of the "NUE" fraction bound to QM-RSV cells cultured at $41^{\circ} \mathrm{C}$ was of the same level as that of the cells cultured at $35.5^{\circ} \mathrm{C}$ in suspension. These findings suggest that cell-substratum attachment and cell-cell adhesion are qualitatively distinct. Cadherin and neural cell-adhesion molecule (NCAM) are known to be associated with cell-cell adhesion, whereas, integrin, fibronectin, and other factors are related to cell-substratum attachment 
$(1,3,6,16)$. Possibly, the "NUE" fraction interacts with these components in different ways, or the adhesion molecules on the cells examined differ quantitatively.

Cell aggregation and adhesion are important phenomena in cell biology. These phenomena involved in intercellular recognition are essential for normal morphogenesis and complicated tissue formation $(17,18)$. In fact, cell adhesion molecules, such as cadherin and NCAM, are considered to play important roles in development $(3,16)$. We are now examining the interactions of the "NUE" fraction with these cell adhesion molecules.

\section{REFERENCES}

1. Buck, C.A. and Horwitz, A.F. 1987. Cell surface receptors for extracellular matrix molecules. Annu. Rev. Cell Biol., 3: 179-205.

2. Chin, H.P. and Blankenhorn, D.H. 1968. Separation and quantitative analysis of serum lipoproteins by means of electrophoresis on cellulose acetate. Clin. Chim. Acta, 20: 305-314.

3. Edelman, G.M. 1985. Cell adhesion and the molecular processes of morphogenesis. Annu. Rev. Biochem., 54: 135-169.

4. Edelman, G.M. and Yahara, I. 1976. Temperature-sensitive changes in surface modulating assemblies of fibroblasts transformed by mutants of Rous sarcoma virus. Proc. Natl. Acad. Sci. USA, 73: 2047-2051.

5. Heifetz, A., Kegnan, R.W., and Elbein, A.D. 1979. Mechanism of action of tunicamycin on the UDP-GlcNAc: Dolichylphosphate GlcNAc-1-phosphate transferase. Biochemistry, 18: 2186-2192.

6. HyNES, R.O. 1987. Integrins: A family of cell surface receptors. Cell, 48: 549-554.

7. Kagawa, Y. 1967. Preparation of ${ }^{3} \mathrm{H}$-acetyl-ATPase (coupling factor 1). In Methods in Enzymology (R.W. Estabrook and M.E. Pullman eds.). Academic Press, New York, Vol. 10, pp. 526-528.
8. Kim, J., Adachi, T., Hirayama, E., Yabubayashi, T., and OKADA, Y. 1992. Differentiation of quail myoblasts transformed with a temperature sensitive mutant of Rous sarcoma virus. I. Relationship between differentiation and tyrosine kinase of src gene product. Cell Struct. Funct., 17: 237-247.

9. Kim, J., AdACHI, T., SAIUCHI, M., and Asada, A. 1992. Differentiation of quail myoblasts transformed with a temperature sensitive mutant of Rous sarcoma virus. II. Relationship of myoblast fusion with calcium and temperature. Cell Struct. Funct., 17: 249-255.

10. LAEMMLI, U.K. 1970. Cleavage of structural proteins during the assembly of the head of bacteriophage T4. Nature, 227: $680-685$.

11. Lowry, O.H., Rosebrough, N.J., FARR, A.L., and RANDALL, R.J. 1951. Protein measurement with the folin phenol reagent. J. Biol. Chem., 193: 265-275.

12. Noonan, K.D., Renger, H.C., Bashlico, C., and Burger, M.M. 1973. Surface changes in temperature-sensitive simian virus 40-transformed cells. Proc. Natl. Acad. Sci. USA, 70: 347-349.

13. ROHRSCHNEIDER, L.R. 1980. Adhesion plaques of Rous sarcoma virus-transformed cells contain the $s r c$ gene product. Proc. Natl. Acad. Sci. USA, 77: 3514-3518.

14. Rosenblith, J.Z., UkeNa, T.E., YiN, H.H., Berlin, R.D., and KARNOVSKY, M.J. 1973. A comparative evaluation of the distribution of concanavalin A-binding sites on the surfaces of normal, virally-transformed, and protease-treated fibroblasts. Proc. Natl. Acad. Sci. USA, 70: 1625-1629.

15. Takatsuki, A., Kohno, K., and Tamura, G. 1975. Inhibition of biosynthesis of polyisoprenol sugars in chick embryo microsomes by tunicamycin. Agr. Biol. Chem., 39: 2089-2091.

16. TaKeICHI, M. 1990. Cadherins: A molecular family important in selective cell-cell adhesion. Annu. Rev. Biochem., 59: 237252.

17. Townes, P.L. and Holtfreter, J. 1955. Directed movements and selective adhesion of embryonic amphibian cells. J. Exp. Zool., 128: 53-120.

18. WiLSON, H.V. 1907. On some phenomena of coalescence and regeneration in sponge. J. Exp. Zool., 5: 245-258.

(Received for publication, May 20, 1993

and in revised form, July 16, 1993) 